\section{Four Levels of Soil Water Depletion Minimally Affect Carambola Phenological Cycles}

\author{
Rashid Al-Yahyai ${ }^{1}$, Bruce Schaffer ${ }^{1,3}$, Frederick S. Davies ${ }^{2}$, and \\ Jonathan H. Crane ${ }^{1}$
}

Additional INDEX wORDs. star fruit, Averrboa cavambola, tropical fruit, flushing, shoot growth, flowering, fruiting

Summary. Phenological cycles were determined for carambola (Averrboa carambola) trees in a gravelly loam soil at four different soil water depletion (SWD) levels in containers and in an orchard in southern Florida. The phenological cycles of young trees grown in containers were not as well defined as those of mature trees in an orchard. Shoot extension of trees in the orchard and containers was observed from the first week of March until the third week of December. Two peak flowering periods occurred during the first week of March, and from mid-September to mid-October. The major fruit harvest periods were August and December. Shoot flushing, extension shoot growth, flowering, and fruiting showed little response to irrigation at four SWD levels. This lack of response was likely caused by sufficient soil water due to precipitation and capillary rise from the high water table located about 1-2 m below the soil surface. Regardless of the lack of SWD effects on phenological cycles of carambola, the periodicity of shoot flushing, extension shoot growth, flowering, and fruiting and the intensity of these phenological events elucidated in this study should provide useful guidelines for carambola orchard management in southern Florida.

$\mathrm{T}$ he phenological cycle describes the morphological developmental pattern of tree crops (Cull, 1986). In perennial evergreen trees such as carambola, also called star fruit, the annual phenological cycle consists of multiple factors operating in synchrony, producing multi-order interactions that influence productivity (Cull, 1986). This pattern depends on species, cultivar, management, and environment. Environmental factors, however, are considered the most important factors that affect tree performance and management strategies (Whiley et al., 1988).

The phenological cycle of tropical fruit trees is influenced by climatic conditions, mainly temperature and precipitation (Cull, 1986). Just as the

\footnotetext{
${ }^{1}$ University of Florida, IFAS, Tropical Research and Education Center, 18905 S.W. 280 Street, Homestead, FL 33031.

${ }^{2}$ Department of Horticultural Sciences, University of Florida, 1129 Fifield Hall, P.O. Box 110690, Gainesville, FL 32611.

Florida Agricultural Experiment Station Journal Series No. R-10615. We thank Yuncong Li and Thomas Obreza for helpful comments and suggestions related to this study. We also thank Ramon Littell of the University of Florida, IFAS, Statistics Department for assistance with statistical analyses.

${ }^{3}$ To whom reprint requests should be addressed; e-mail: bas@ifas.ufl.edu
}

phenology of deciduous temperate trees is mainly determined by seasonal variations in temperature and photoperiod, the phenology of tropical fruit trees is affected by seasonal variability in water availability (Reich and Borchert, 1984). Phenological cycles of tropical evergreen trees are less well defined than those of temperate fruit trees. Tropical fruit growers must recognize annual critical growth changes in order to utilize growth cycles as orchard management tools (Whiley et al., 1988). Orchard cultural practices affect vegetative and reproductive development throughout the annual phenological cycle of carambola trees. In addition to environmental factors, cultural practices such as cultivar selection (Salakpetch et al., 1990), mulching (George et al., 2000, 2001), fertilization (Campbell, 1985, 1989; Crane, 1994; Knight, 1982), and pruning (Crane et al., 1991; Núñez-Elisea and Crane, 1998, 2000) also influence vegetative and reproductive growth of carambola trees.

In their native, tropical habitat, carambola trees grow, flower, and fruit year-round (Núñez-Elisea and Crane, 2000). Trees may produce new flushes, flowers, and immature and mature fruit simultaneously (Galán Saúco et al., 1993). Núñez-Elisea and Crane (1998) qualitatively described the flowering and fruiting cycles of carambola trees in southern Florida. In subtropical conditions such as those of southern Florida, carambola tree canopy development is poor and trees defoliate from December to March presumably due to low temperatures, dry winds, and high light intensity (Núñez-Elisea and Crane, 1998). Trees begin to refoliate from March to mid-May and may continue to produce new leaves until midOctober (Núñez-Elisea and Crane, 1998). Shoots of carambola alternate growth with periods of quiescence. Apical growth results in an extension of the shoot axis, with each growth flush containing between eight and 12 leaves (Núñez-Elisea and Crane, 1998). Shoot flushing is enhanced by warm weather and rain. Shoots formed during the spring flush about four to five times per growth season but those formed in the late summer normally flush once before shoot extension growth ceases in the fall (Núñez-Elisea and Crane, 1998).

Carambola has several flowering periods and may flower continuously during the year under favorable environmental conditions (Núñez-Elisea and Crane, 1998, 2000). The carambola production season in Florida extends from mid-July to mid-February (Campbell et al., 1985; Núñez-Elisea and Crane, 1998, 2000). Two reproductive growth phases occur in southern Florida. The first phase is characterized by a flowering peak in May and with fruit maturing from July to October. The second phase has a peak bloom in September with fruit maturing from December to February (Campbell etal., 1985; Núñez-Elisea and Crane, 1998).

\begin{tabular}{llll}
\hline $\begin{array}{l}\text { Units } \\
\text { To convert U.S. to SI, } \\
\text { multiply by }\end{array}$ & U.S. unit & SI unit & $\begin{array}{l}\text { To convert SI to U.S., } \\
\text { multiply by }\end{array}$ \\
\hline 0.3048 & $\mathrm{ft}$ & $\mathrm{m}$ & 3.2808 \\
3.7854 & gal & $\mathrm{L}$ & 0.2642 \\
2.5400 & inch(es) & $\mathrm{cm}$ & 0.3937 \\
25.4000 & inch $(\mathrm{es})$ & $\mathrm{mm}$ & 0.0394 \\
$\left({ }^{\circ} \mathrm{F}-32\right) \div 1.8$ & ${ }^{\circ} \mathrm{F}$ & ${ }^{\circ} \mathrm{C}$ & $\left(1.8 \times{ }^{\circ} \mathrm{C}\right)+32$
\end{tabular}


These flowering phases and the ability of different wood types to flower indicate that floral development is affected by environmental, physiological, and cultural factors (Núñez-Elisea and Crane, 2000). Manipulation of growth and production cycles, therefore, requires an understanding of developmental and phenological properties of the tree.

Soil water content is among the three major growth and productivity determinants (in addition to temperature and nutrition) that can be regulated throughout the phenological cycles of tropical fruit crops (Cull, 1986). Excessive soil water content (Joyner and Schaffer, 1989) and drought (Ismail and Noor, 1996; Ismail et al., 1996; Salakpetch et al., 1990) decrease carambola growth and yield. However, little is known about the response of carambola phenological cycles to soil water depletion (SWD) in gravelly loam soils in a subtropical climate like that of Florida. Krome gravelly loam soil drains very rapidly due to the large percentage of large rock fragments creating several large air spaces (MuñozCarpena et al., 2002; Nuñez-Elisea et al., 2001). Therefore, even when total monthly rainfall exceeds total monthly $\mathrm{ET}$, water stress can occur from short durations of very dry soil between rain or irrigation events.

A recent irrigation management survey indicated that irrigation frequency and duration varies widely among tropical fruit producers in south Florida (Li et al., 2000). The frequency and duration of high volume irrigation systems ranged from 1 to 3 times per week from $\mathrm{l}$ to $12 \mathrm{~h}$ per application resulting in 29 to $608 \mathrm{gal} /$ tree per application. In contrast, the frequency and duration of microsprinkler irrigation system use ranged from 1 to $7 \mathrm{~d} /$ week for 0.5 to $7.5 \mathrm{~h}$ per application resulting in 5 to 90 $\mathrm{gal} /$ tree per application. With average ET in southern Florida estimated at $0.013 \mathrm{inch} / \mathrm{d}$ (about 20 to $60 \mathrm{gal} /$ tree per day for mature trees), many producers are over- or underirrigating their trees. This study was carried out to determine the effect of four levels of SWD on the phenological cycles of carambola trees grown in the subtropical climate of southern
Florida and to quantify phenological events with visual rating scales.

\section{Materials and methods}

EXPERIMENTAL SITE AND PLANT MATERIAL. In an orchard, 8-year-old 'Arkin' carambola trees grafted on open-pollinated Golden Star rootstock were visually monitored for phenological growth cycles throughout 2003 . The trees were planted at $4.5 \mathrm{~m}$ within and $6.0 \mathrm{~m}$ between rows and the orchard was surrounded by an artificial (polypropylene ribbon shadecloth) windbreak on the northern, eastern, and western perimeters and sapodilla (Manilkara zapota) trees on the southern perimeter of the orchard. All the trees were topped to a $2.7-\mathrm{m}$ height on 23 Apr. 2003.

The orchard was located at the Tropical Research and Education Center in Homestead, Fla., at $25.5^{\circ} \mathrm{N}$ latitude and $80.5^{\circ} \mathrm{W}$ longitude. Average monthly temperatures in 2003 were lowest in January $\left(17.9^{\circ} \mathrm{C}\right)$ and the highest $\left(30.4^{\circ} \mathrm{C}\right)$ in July (Fig. 1), which are near the ideal temperature range for growth of carambola (21 to $\left.32{ }^{\circ} \mathrm{C}\right)$ (Ngah et al., 1989). Historical climatic records of Homestead, Fla., for 41 years showed an average annual precipitation of $1571 \mathrm{~mm}, 79 \%$ of which occurred from May through October (Fig. 1). The same pattern occurred during 2003 , when $74 \%$ of the $1606 \mathrm{~mm}$ total precipitation occurred during this period. The soil at the experimental site is Krome very gravelly loam [loamy-skeletal, carbonatic, hyperthermic, Lithic Udorthents (Noble et al., 1996)]. Trees were planted at the intersection of perpendicular trenches that were approximately 50 to $75 \mathrm{~cm}$ wide and $50 \mathrm{~cm}$ deep (Colburn and Goldweber, 1961). A second experiment was also conducted during the same period in 2003 to study the phenological cycle of 2-year-old 'Arkin' carambola trees grafted on Golden Star rootstock planted in 95-L containers on 4 June 2002. The containers were filled with Krome very gravelly loam soil and placed in the field adjacent to the orchard used for the phenological study of mature trees. Fertilizer and pest management were in accordance with standard practices for commercial carambola production in southern Florida (Crane, 1994).

SOIL WATER DEPLETION TREATMENTS. Soil water depletion was determined by monitoring soil water content with multi-sensor capacitance probes (EnviroSCAN; Sentek PTY Ltd., Kent Town, Australia). Three probes per treatment were installed 60 $\mathrm{cm}$ north of the trunk of trees in the orchard and $20 \mathrm{~cm}$ from the trunk of trees in containers. Each probe in the orchard contained four capacitance sensors located at 10-, 20-, 30-, and $50-\mathrm{cm}$ depths in the soil. Sensors were placed at 10-, 20-, and 30-cm depths

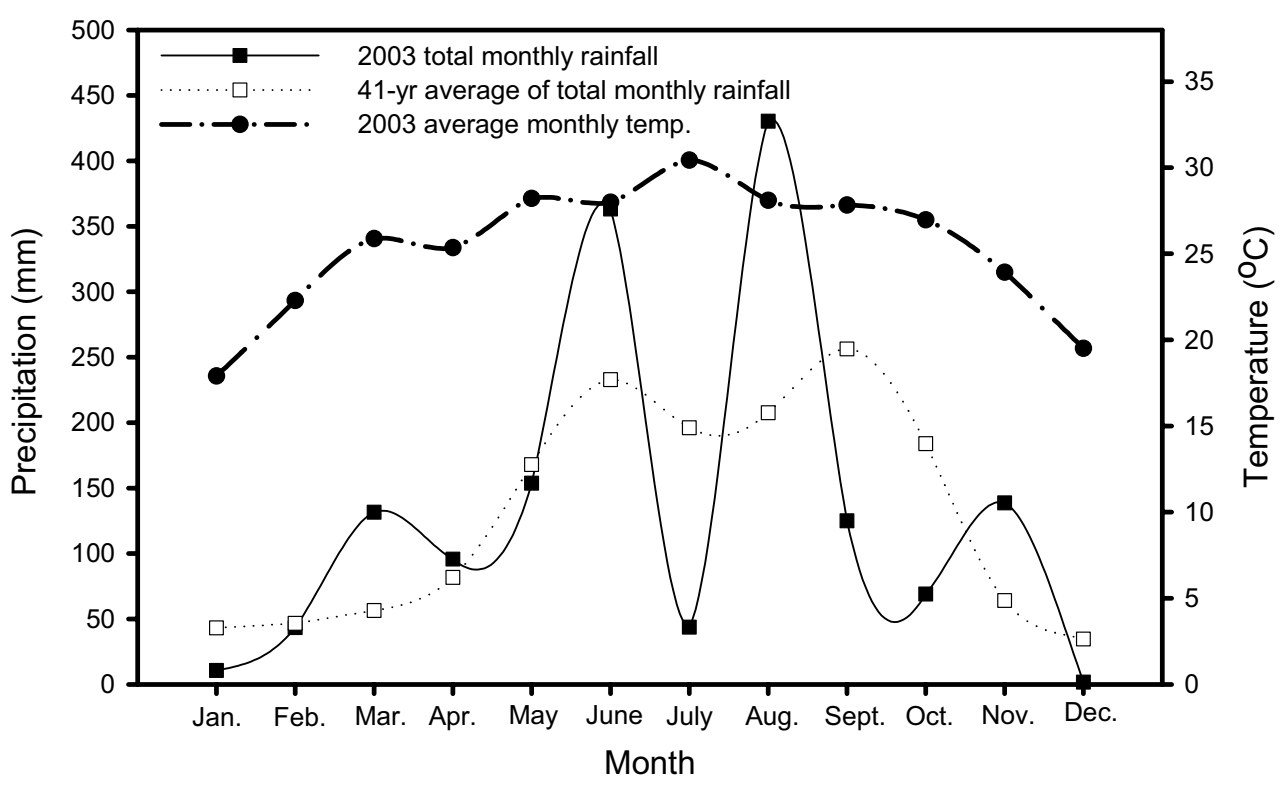

Fig. 1. The 41-year average of total precipitation and 2003 total monthly precipitation and the average monthly temperature in 2003 in Homestead, Fla. (Florida Automated Weather Network, 2003; National Oceanic and Atmospheric Administration, 2003); 1 $\mathrm{mm}=0.0394$ inches; $\left(1.8 \times{ }^{\circ} \mathrm{C}\right)+32={ }^{\circ} \mathrm{F}$. 
in containers. The sensors recorded soil water content every $30 \mathrm{~min}$. Soil water data were stored in a data logger and later downloaded to a portable computer for analysis. Installation of the capacitance probe system in Krome very gravelly loam soils was described previously by Al-Yahyai et al. (2003) and Núñez-Elisea et al. (2001), and technical specifications of the multi-sensor capacitance probes were discussed by Paltineanu and Starr (1997). Soil moisture data from the 10-, 20-, and 30-cm depth sensors were averaged and plotted using EnviroSCAN software (EnviroSCAN $4.0)$. The average soil moisture data from the 10-, 20-, and 30-cm depths of the soil profile were used for imposing SWD treatments because in carambola orchards of southern Florida, roots are generally restricted to the top $30 \mathrm{~cm}$ of soil (Nuñez-Elisea et al., 2001).

Field capacity (FC) values were determined based on the amount of water in the soil after excess water had drained and the rate of downward movement had decreased. Field capacity was determined to be at $34 \%$ volumetric soil water content. Trees in the orchard and in containers were irrigated with microsprinklers (Maxijet, Dundee, Fla.), which had a discharge rate of $89 \mathrm{~L} \cdot \mathrm{h}^{-1}$ and a $360^{\circ}$ wetting pattern.

Levels of soil water depletion were predetermined in the orchard and in containers based on a preliminary study (R. Al-Yahyai, unpublished data) whereby irrigation water was withheld and soil water content was monitored with capacitance probes until leaf yellowing and abscission occurred. Containers were placed on metal bases above the ground to prevent capillary movement of water from the soil to the containers.

Irrigation of the orchard trees was initiated when SWD reached one of the following four levels (where $0 \%$ SWD $=\mathrm{FC}): 0 \%$ to $8 \%$ SWD, which represents $100 \%$ to $92 \%$ of $\mathrm{FC}$; an irrigation frequency and/or duration that is typical in carambola orchards in southern Florida (J.H. Crane, personal observation); $9 \%$ to $11 \%$ SWD; $12 \%$ to $14 \%$ SWD; or $15 \%$ to $17 \%$ SWD, which are considerably below the irrigation frequency and/or duration that is typical in carambola orchards in southern Florida (J.H. Crane, personal observation). Soil water depleted more rapidly in containers than in the orchard. Thus, irrigation of container trees was initiated when SWD reached one of the following four levels: $0 \%$ to $21 \%$ SWD , 22\% to $31 \%$ SWD, $32 \%$ to $50 \%$ SWD, and $51 \%$ to $60 \%$ SWD. The lowest SWD levels were set at $15 \%$ to $17 \%$ in the orchard and $51 \%$ to $60 \%$ in containers, because leaf yellowing and abscission that occurred at those SWD levels were interpreted as visible symptoms of tree water stress.

Phenological observations. Orchard and container-grown trees were visually evaluated weekly for 37 weeks in 2003. Observations of vegetative and reproductive development included: 1) shoot flushing: shoot growth following bud break or resumption of growth of quiescent shoots. Following the initial post-winter shoot flush, observations were made of new axillary bud break (George et al., 2000); 2) shoot growth: the relative number of continuously growing axillary shoots; 3 ) flowering: growth of the panicle from fully developed buds to flower opening (bloom) (Whiley et al., 1988). Most panicles were formed on branches on the periphery of the canopy, and quiescent buds on older branches. Flowers were also formed on scaffold branches and on the main trunk (Núñez-Elisea and Crane, 2000); 4) fruit load: the relative number of fruit per tree. Fruit from six trees per treatment were completely harvested on 18-22 Aug. (summer harvest) and on 15-19 Dec. (winter harvest), which coincided with the peak harvesting season in southern Florida in 2003. Root growth was not quantified because the extremely hard mineral soil makes it extremely difficult to accurately assess root growth without severely damaging the roots.

EXPERIMENTAL DESIGN AND STATISTICAL ANALYSIS. Treatments in the orchard and containers were arranged in a completely randomized design. Each treatment in the orchard consisted of three rows (replications) with a maximum of five trees per row. In the orchard, the total numbers of trees per treatment were 15 for $0 \%$ to $8 \%$ SWD, 11 for $9 \%$ to $11 \%$ SWD, 11 for $12 \%$ to $14 \%$ SWD, and 14 for the $15 \%$ to $17 \%$ SWD treatment. For trees in containers, each treatment was replicated three times with two trees per replication. The lack of uniformity in the number of trees per row (replication) among treatments in the orchard was due to some rows containing unhealthy trees not used in the experiment or support posts for the artificial windbreak that resulted in an uneven number of trees per row. Each previously described phenological trait was evaluated based on a score of 0 to 5 . Ranking was based on the following visual rating scale: 0 (none), 1 (very low), 2 (low), 3 (medium), 4 (high), and 5 (very high to maximum). A similar approach was previously used to evaluate carambola canopy leaf color (George et al., 2000) and flowering (Crane et al., 1991; George et al., 2001). The ranked data were analyzed using the Kruskal-Wallis non-parametric test for unequal population sample size (Miller, 1980; Neter et al., 1990). Data were analyzed using the NPARIWAY procedure in SAS (SAS Institute, Cary, N.C.). Multiple mean comparisons were performed as described by Miller (1980) and Neter et al. (1990).

\section{Results}

Shoot Flush. Shoot flushing began during the last week of February for trees in the orchard and reached a peak by mid-March (Fig. 2A.). After the initial shoot flush in the spring, trees continued to flush but at a low level until the third week of October. Another small increase in shoot flushing occurred following harvest at the end of September and peaked at the beginning of October. The highest average spring flush rating, 4.6 , occurred in the middle of March for trees in the $9 \%$ to $11 \%$ SWD treatment. The fall flushing was highest for trees in the $12 \%$ to $14 \%$ SWD treatment with an average rating of 1.8 in the first week of October. There were no significant differences in shoot flushing among treatments $(P \leq 0.05)$ during the peak spring and fall shoot flushes. Shoot growth ceased toward the end of October and trees became quiescent during November but resumed growth in February. On Feb. 28, shoot flushing was significantly different between trees in the $0 \%$ to $8 \%$ SWD treatment that had a high rating (3.8) and those in the $12 \%$ to $14 \%$ SWD treatment with a low rating (2.8). No significant differences in shoot flushing ratings were observed among the other treatments on that date (Table 1). Shoot flushing ratings were not significantly different among treatments for the rest of the year.

Shoot growth of container-grown carambola trees began during the third week of February (Fig. 2B). However, 


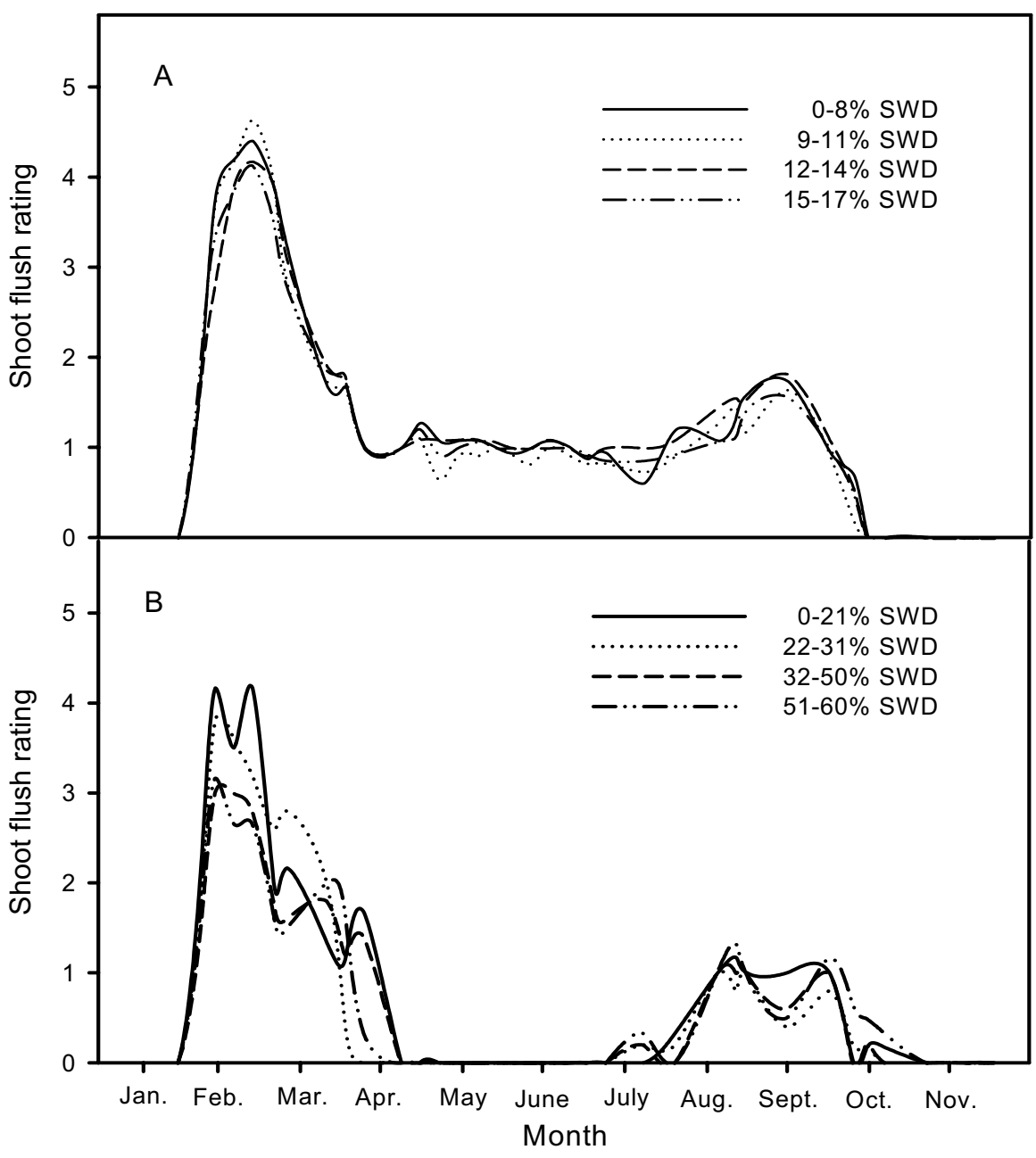

Fig. 2. The mean shoot flush ratings of carambola trees in Krome very gravelly loam soil of southern Florida in 2003 irrigated at four levels of soil water depletion (SWD) in an orchard (A) ( $\mathrm{n}=$ three replications with 11-14 trees per replication) and in containers (B) $(\mathbf{n}=$ three single-tree replications $)$. Shoot flush ratings were based on visual rankings from 0 (none) to 5 (very high to maximum) of the amount of shoot growth following budbreak.

unlike orchard trees, shoot flushing of container-grown trees fluctuated throughout the year and no bud break was observed from mid-May to midJuly and from mid-November until the end of December. Trees in the $0 \%$ to $21 \%$ SWD and $22 \%$ to $31 \%$ SWD treatments had higher shoot flushing ratings than trees in the $32 \%$ to $50 \%$ and $51 \%$ to $60 \%$ SWD treatments from mid-February to mid-May. Containergrown trees started a new shoot flush in August that reached a peak by the first week of September. Shoot flushing continued at a low level until it ceased by the second week of November. Significant differences were observed on $25 \mathrm{Apr}$. between trees in the $0 \%$ to $21 \%$ SWD treatment that had a low shoot flushing rating of 1.7 and trees in the $22 \%$ to $31 \%$ SWD treatment that had no shoot flushes (Table 2).

Table 1. The effect of soil water depletion (SWD) on shoot flushing, axillary shoot growth, flowering, and fruit load of orchard-grown carambola trees in 2003.

\begin{tabular}{|c|c|c|c|c|c|c|c|c|c|c|}
\hline \multirow[b]{3}{*}{ Treatments } & \multicolumn{10}{|c|}{ Ratings $^{\mathrm{z}}$} \\
\hline & \multirow{2}{*}{$\begin{array}{c}\text { Shoot flushing } \\
28 \text { Feb. }^{\mathrm{y}}\end{array}$} & \multicolumn{6}{|c|}{ Axillary shoot growth } & \multicolumn{2}{|c|}{ Flowering } & \multirow{2}{*}{$\frac{\text { Fruit load }}{30 \text { May }}$} \\
\hline & & 23 May & 30 May & 7 June & 13 June & 3 July & 8 Aug. & 1 Oct. & 17 Oct. & \\
\hline $9 \%$ to $11 \%$ SWD & $3.7 \mathrm{ab}$ & $4.7 \mathrm{a}$ & $4.8 \mathrm{a}$ & $4.8 \mathrm{a}$ & $4.7 \mathrm{a}$ & $4.4 \mathrm{ab}$ & $3.8 \mathrm{a}$ & $4.6 \mathrm{a}$ & $3.8 \mathrm{a}$ & $3.3 \mathrm{ab}$ \\
\hline $12 \%$ to $14 \%$ SWD & $2.8 \mathrm{~b}$ & $3.9 \mathrm{~b}$ & $4.1 \mathrm{~b}$ & $3.9 \mathrm{~b}$ & $3.6 \mathrm{~b}$ & $3.7 \mathrm{~b}$ & $3.2 \mathrm{~b}$ & $3.8 \mathrm{ab}$ & $3.0 \mathrm{~b}$ & $2.7 \mathrm{~b}$ \\
\hline $15 \%$ to $17 \%$ SWD & $3.4 \mathrm{ab}$ & $4.5 \mathrm{ab}$ & $4.5 \mathrm{ab}$ & $4.1 \mathrm{ab}$ & $3.7 \mathrm{~b}$ & $3.9 \mathrm{ab}$ & $3.3 \mathrm{ab}$ & $3.5 \mathrm{~b}$ & $3.0 \mathrm{~b}$ & $3.6 \mathrm{a}$ \\
\hline
\end{tabular}

${ }^{2}$ Rating was based on the following rating: 0 (none), 1 (very low), 2 (low), 3 (medium), 4 (high), and 5 (very high to maximum).

Dates listed when significant differences among treatments were detected (total number of observation dates was 37 ).

${ }^{x}$ Different letters within columns indicate significant differences among means according to the Kruskal-Wallis non-parametric test, $\alpha \leq 0.1$.

Table 2. The effect of soil water depletion (SWD) on shoot flushing, axillary shoot growth, and flowering of containergrown carambola trees in 2003.

\begin{tabular}{|c|c|c|c|c|c|c|c|c|}
\hline \multirow[b]{3}{*}{ Treatments } & \multicolumn{8}{|c|}{ Ratings $^{\mathrm{z}}$} \\
\hline & \multirow{2}{*}{$\begin{array}{c}\text { Shoot flushing } \\
25 \mathrm{Apr}^{\mathrm{y}}\end{array}$} & \multicolumn{5}{|c|}{ Axillary shoot growth } & \multicolumn{2}{|c|}{ Flowering } \\
\hline & & 25 Apr. & 3 May & 7 June & 8 Aug. & 19 Sept. & 7 Mar. & 14 Mar. \\
\hline $0 \%$ to $21 \%$ SWD & $1.7 \mathrm{a}^{\mathrm{x}}$ & $3.3 \mathrm{~b}$ & $4.8 \mathrm{a}$ & $4.8 \mathrm{a}$ & $2.8 \mathrm{a}$ & $4.0 \mathrm{a}$ & $2.8 \mathrm{a}$ & $3.2 \mathrm{a}$ \\
\hline $22 \%$ to $31 \%$ SWD & $0.0 \mathrm{~b}$ & $4.8 \mathrm{ab}$ & $4.4 \mathrm{ab}$ & $4.4 \mathrm{ab}$ & $2.0 \mathrm{ab}$ & $3.8 \mathrm{ab}$ & $2.0 \mathrm{ab}$ & $2.2 \mathrm{ab}$ \\
\hline $32 \%$ to $50 \%$ SWD & $1.4 \mathrm{ab}$ & $4.6 \mathrm{ab}$ & $3.4 \mathrm{~b}$ & $3.2 \mathrm{~b}$ & $1.4 \mathrm{ab}$ & $3.6 \mathrm{ab}$ & $1.4 \mathrm{ab}$ & $1.8 \mathrm{ab}$ \\
\hline $51 \%$ to $60 \%$ SWD & $0.3 \mathrm{ab}$ & $5.0 \mathrm{a}$ & $4.2 \mathrm{ab}$ & $4.0 \mathrm{ab}$ & $1.2 \mathrm{~b}$ & $3.0 \mathrm{~b}$ & $1.2 \mathrm{~b}$ & $1.0 \mathrm{~b}$ \\
\hline
\end{tabular}

${ }^{2}$ Rating was based on the following rating: 0 (none), 1 (very low), 2 (low), 3 (medium), 4 (high), and 5 (very high to maximum).

y Dates listed if significant differences among treatments were detected (total number of observation dates was 37 ).

'Different letters within columns indicate significant differences among means according to the Kruskal-Wallis non-parametric test, $\alpha \leq 0.1$. 
Although shoot flushing varied among treatments, no further significant differences among irrigation treatments were observed.

EXTENSION SHOOT GROWTH. Shoot extension of carambola trees in the orchard was observed from the first week of March until the third week of December. Extension shoot growth was very rapid at the beginning of the growing season in March with a gradual decrease in growth by the end of September followed by a rapid decline from October to November until growth ceased toward the end of December (Fig. 3A). Shoot growth ratings of the axillary shoots fluctuated from March to September.

During the initial growth of the axillary shoots of trees in the orchard in March and April, there were no significant differences in shoot growth ratings among treatments (data not shown). However, trees in the $9 \%$ to $11 \%$ SWD treatment had a significantly higher shoot growth rating than trees in the $12 \%$ to $14 \%$ SWD treatment on 23 May, 30 May, 7 June, and 13 June. Also significantly more shoot growth occurred in trees in $0 \%$ to $8 \%$ SWD than in the $12 \%$ to $14 \%$ SWD treatment. In addition, trees in the $0 \%$ to $8 \%$ and $9 \%$ to $11 \%$ SWD treatments had significantly higher shoot growth ratings than trees in the $12 \%$ to $14 \%$ SWD treatment on 8 Aug. No significant differences in shoot growth rating were observed between trees irrigated at $0 \%$ to $8 \%$ and $15 \%$ to 17\% SWD (Table 1).

Container-grown trees had similar shoot growth patterns to those of orchard trees throughout the year (Fig. $3 B)$. Shoot growth of container-grown trees was high during the last week of March and the first week of April. Unlike orchard trees, however, shoot growth ratings of trees in containers did not gradually decrease until September (Fig. 3B). Trees in the $32 \%$ to $50 \%$ and $51 \%$ to $60 \%$ SWD treatments generally had fewer shoots growing than trees in the $0 \%$ to $21 \%$ or $22 \%$ to $31 \%$ SWD treatments.

Carambola trees in the $0 \%$ to $21 \%$ SWD had significantly fewer axillary shoots growing than trees in the $51 \%$ to $60 \%$ SWD treatment on $25 \mathrm{Apr}$. (Table 2). However, trees in the $0 \%$ to $21 \%$ SWD treatment had more axillary shoots growing than trees in the $32 \%$ to $50 \%$ SWD treatment on 30 May and 7 June, and the $51 \%$ to $60 \%$ SWD treatment on 19 Sept. Axillary shoot

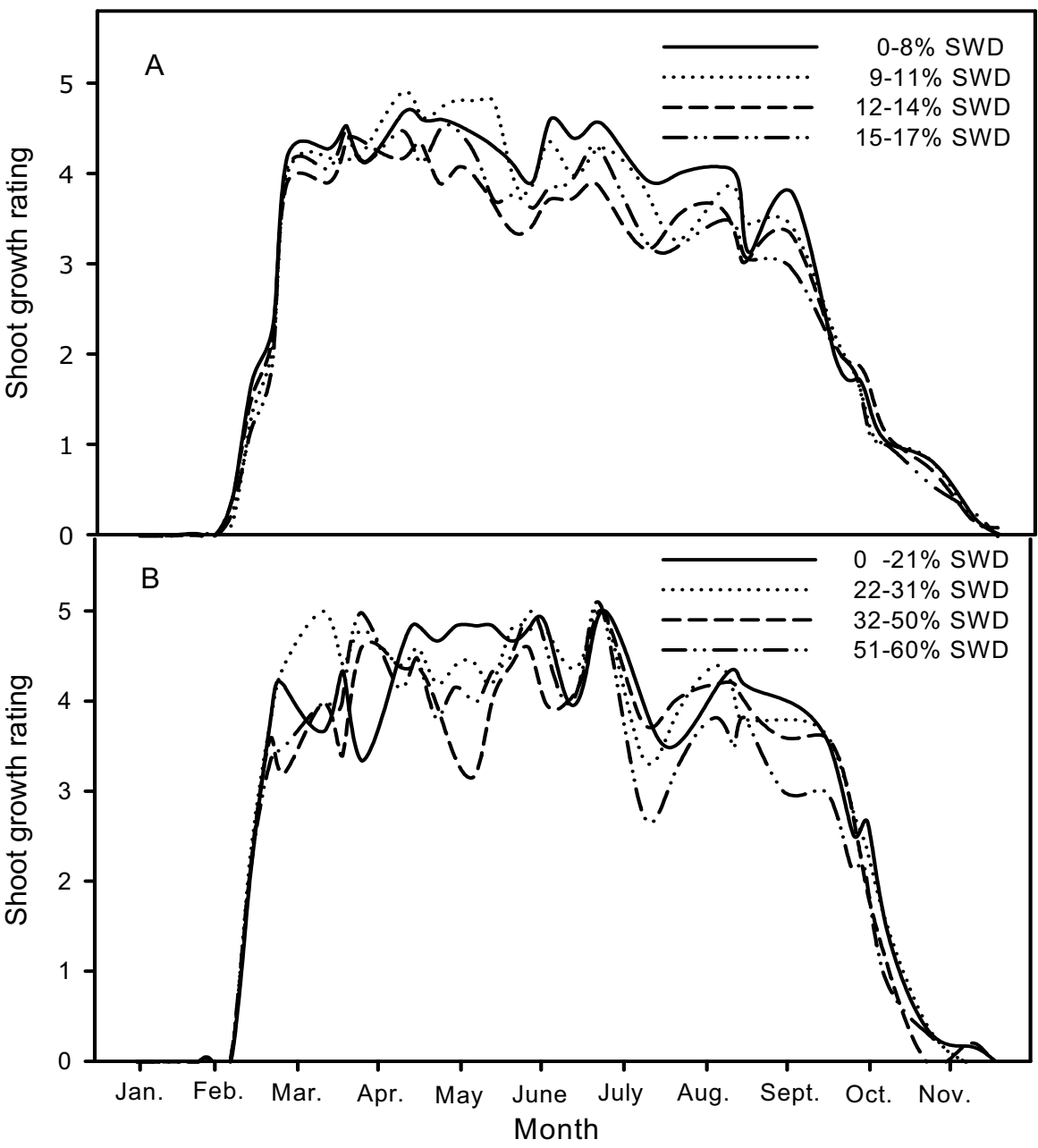

Fig. 3. The mean shoot growth ratings of carambola trees in Krome very gravelly loam soil of southern Florida in 2003 irrigated at four levels of soil water depletion (SWD) in an orchard $(\mathrm{A})(\mathrm{n}=$ three replications with $11-14$ trees per replication $)$ and in containers $(B)(n=$ three single-tree replications $)$. Shoot growth ratings were based on visual rankings from 0 (none) to 5 (very high to maximum) of the number of continuously growing axillary shoots.

growth ratings of these trees were significantly higher than for trees in the $32 \%$ to $50 \%$ SWD treatment (Table 2 ) on 30 May and 7 June. Shoot growth ratings of trees in the $0 \%$ to $21 \%$ SWD treatment were significantly higher than those of trees in the $51 \%$ to $60 \%$ SWD treatment.

Flowering. Flowering of trees in the orchard was first observed during the first week of March (Fig. 4A). However, fruit set from this bloom was very low (data not shown). During the second half of April, flowering increased and reached its peak during the last 2 weeks of May. Flowering then continued at a moderate level until the fruit were harvested during the third week of August. Following harvest, flowering peaked again from mid-September to mid-October. The number of flowers decreased following this period and flowering ceased by the end of December (Fig. 4A). Trees in the $9 \%$ to $11 \%$ SWD treatment had a significantly higher flowering rating than trees in the $15 \%$ to $17 \%$ SWD treatment on 1 Oct. (Table 1). On 17 Oct., trees in the $9 \%$ to $11 \%$ SWD treatment had the highest flowering rating (Table $\mathrm{l}$ ).

The first flowering peak in container trees occurred in March and flowering declined toward the end of April (Fig. 4B). Low flowering ratings were observed from mid-May to the end of July. An increase in flowering began in August which reached its peak by the end of October, and then declined by December (Fig. 4B). Container-grown trees had lower flowering ratings during the summer and fall compared to those of orchard trees. On 7 and 14 Mar., trees in the 
Fig. 4. The mean flowering ratings of carambola trees in Krome very gravelly loam soil of southern Florida in 2003 irrigated at four levels of soil water depletion (SWD) in an orchard (A) ( $\mathrm{n}=$ three replications with 11-14 trees per replication) and in containers (B) $(\mathbf{n}=$ three single-tree replications). Flowering ratings were based on visual ratings from 0 (none) to 5 (very high to maximum) of growth of the panicle from the fully developed bud stage to flower opening.

$0 \%$ to $21 \%$ SWD treatment had a significantly higher flowering rating than trees in the $51 \%$ to $60 \%$ SWD treatment (Table 2).

Fruiting. In the orchard, fruit that were not harvested in the winter remained on the tree until March when they ripened and abscised (Fig. 5 ). Trees did not set fruit from newly formed flowers until the second half of April. Fruit production continued as new flowers produced and set fruit for the rest of the year. The major fruit harvest periods were August and December. However, trees continuously produced fruit during the year. Orchard trees in the $15 \%$ to $17 \%$ SWD treatment had a significantly higher fruit number rating on 30 May than trees in the $12 \%$ to $14 \%$ SWD treatment but fruit number ratings in the $15 \%$ to $17 \%$ SWD and $12 \%$ to $14 \%$ SWD treatments did not differ from those in the $9 \%$ to $11 \%$ SWD and $0 \%$ to $8 \%$ SWD treatments (Table 1).

Fruit number ratings for container-grown trees were not significantly different among treatments throughout the year. This was attributed to the low number of fruit produced and the variation in fruit yield among container-grown trees in 2003 (data not shown).

\section{Discussion}

IrRIGATION TREATMENTS. Krome very gravelly loam soil has two distinct fractions, coarse gravel (51\%) and fine loam $(49 \%)$, which correspond to two distinct soil moisture regions. A large portion of water $(>50 \%)$ drains from Krome soil very quickly (within a few minutes) after crops are irrigated as a result of the low water-holding capacity of the gravelly fraction (MuñozCarpena et al., 2002; Muñoz-Carpena, personal communication). The gravelly portion of the soil has a much greater rate of soil moisture depletion than the fine loam portion (Muñoz-Carpena
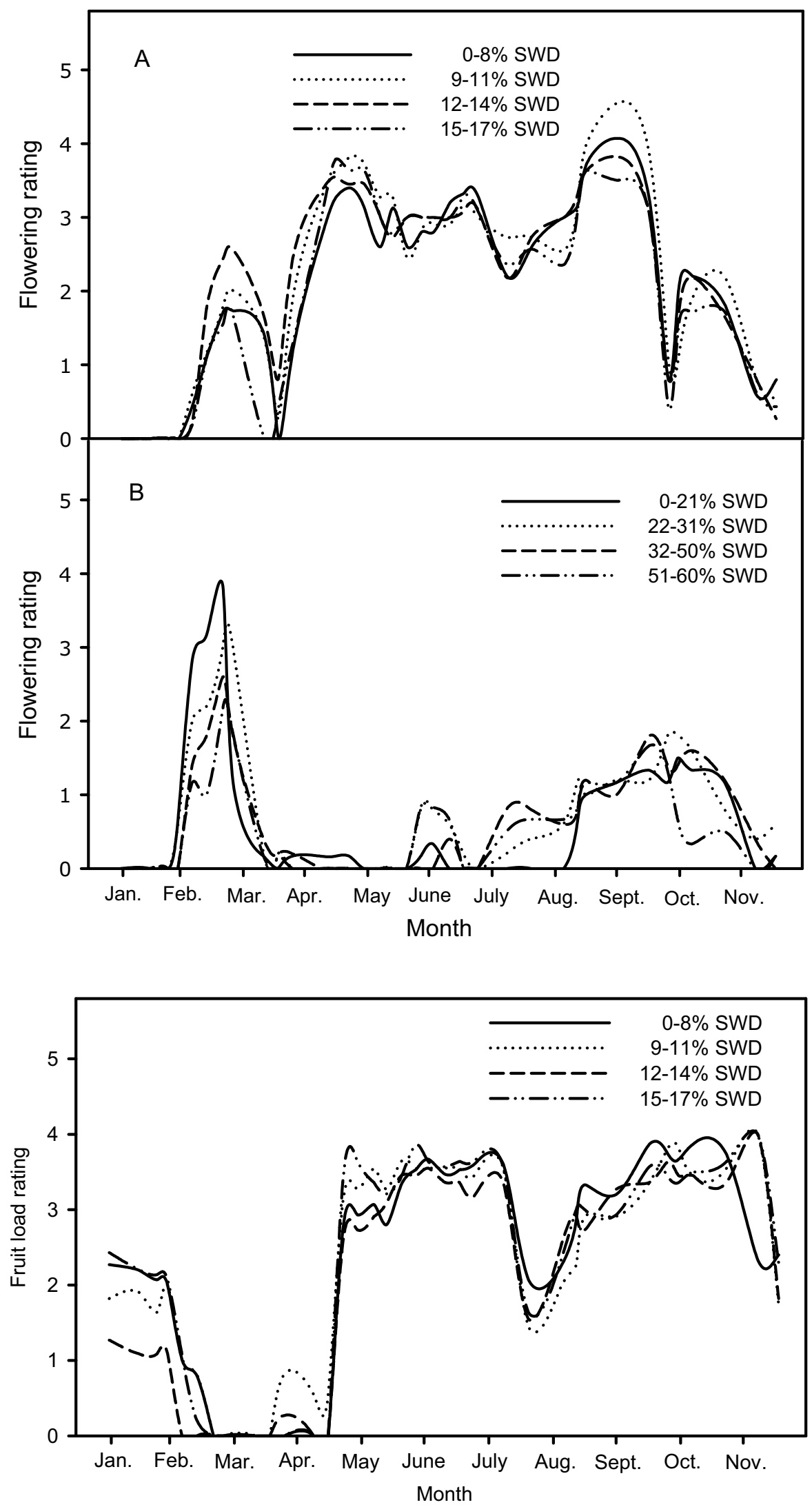

Fig. 5. The mean fruit load rating of carambola trees in Krome very gravelly loam soil of southern Florida in 2003 irrigated at four levels of soil water depletion (SWD) in an orchard ( $\mathrm{n}=$ three replications with $11-14$ trees per replication). Fruit load ratings were based on visual rankings from 0 (none) to 5 (very high to maximum) of the number of fruit per tree. 
et al., 2002). The more rapid soil water depletion in containers than in the orchard was presumably due to an apparent greater portion of coarse gravel in containers than the orchard as a result of transferring the soil from the field to containers and thus disrupting the soil texture. In most soil types, orchard trees can tolerate lower SWD levels than container-grown plants due to less root restriction in the orchard than in containers. However, in orchards in Krome very gravelly loam soil trees are planted in the perpendicular intersections of mechanically excavated trenches and roots do not penetrate the native limestone rock surrounding these trenches (Nuñez-Elisea et al., 2001). Thus, the ratio of root to shoot volume is often lower for orchard trees than for container-grown trees, resulting in a greater sensitivity of orchard trees to water stress compared to container-grown trees.

Shoot flushing of carambola trees in the orchard and in containers was not affected by irrigation at four levels of SWD under the subtropical climatic conditions of southern Florida in 2003. The lack of response was presumably due to sufficient soil water from precipitation in the orchard and in containers (Fig. 1). In addition, capillary rise of water from the high water table (1-2 $\mathrm{m}$ below soil surface) to the root zone may have minimized SWD treatment effects on orchard trees.

Overall shoot growth was not affected by SWD treatments in the orchard. This lack of response was presumably due to soil water depletion not reaching sufficiently low levels to cause a reduction in shoot growth. In Malaysia, Bookeri (1996) also found no response of overall growth of carambola trees in an orchard to irrigation due to sufficient rainfall following a drought. Similarly, Núñez-Elisea and Crane (1998) reported that in southern Florida, vegetative growth of carambola occurred throughout the spring and summer months due to the presence of warm temperatures and rain. A reduction of shoot growth of fruit crops in response to water stress is well documented (Hsiao and Acevedo, 1974; Lakso, 1985). A reduction in vegetative growth in response to water stress was reported previously for container-grown (Ismail et al., 1994; Ismail and Noor, 1996) and field-grown carambola trees (Ismail et al., 1996).
In general the lack of growth and fruit production responses in the orchard to as much as $15 \%$ to $17 \%$ SWD suggests there is substantial potential for over irrigation under the climatic and soil conditions of southern Florida. Considerably less irrigation than is typically applied by growers resulted in no horticulturally significant effects on tree phenology.

Phenological observations. In the subtropical climate of southern Florida, carambola trees did not produce shoot flushes until mid-February in 2003. Low ambient and soil temperatures and dry winds have been cited as the reason for this lack of shoot development during that time of year in south Florida (Campbell et al., 1985; George et al., 2002a, 2002b; NúñezElisea and Crane, 1998, 2000) in comparison to tropical climates where carambola continuously produce new shoots (Núñez-Elisea and Crane, 2000; Galán Saúco et al., 1993). The peak amount of shoot flushing occurred in the spring following a period of quiescence and a second peak of shoot growth flush occurred in the fall following the summer harvest, before shoot growth ceased in the winter. Continuous shoot growth flushing throughout the spring, summer, and winter was due to an alteration of growth and quiescence as observed by Núñez-Elisea and Crane (1998). Following topping of orchard trees in April, pruned branches produced 70\% of the new growth in May and June, whereas container-grown trees did not flush during this period. Pruning of carambola increased vegetative shoot flushing (Núñez-Elisea and Crane, 2000).

The two flowering periods (from April to June and from August to October) that we observed in southern Florida were also observed by Campbell et al. (1985) and Núñez-Elisea and Crane (1998). Under optimum environmental conditions, however, carambola may have numerous flowering periods throughout the year (Núñez-Elisea and Crane, 1998, 2000; Tidbury, 1976).

Regardless of the lack of SWD effects on phenological cycles of carambola, the periodicity of shoot flushing, extension shoot growth, flowering, and fruiting and the intensity of these phenological events elucidated in this study should provide useful guidelines for carambola irrigation, fertilization and pest control practices in southern Florida.

\section{Literature cited}

Al-Yahyai, R., B. Schaffer, and F.S. Davies. 2003. Monitoring soil water content for irrigation scheduling in a carambola orchard in a gravelly limestone soil. Proc. Fla. State Hort. Soc. 116: 37-41.

Bookeri, M. 1996. Effect of irrigation on carambola (Averrhoa carambola) production in drought prone areas. Proc. Intl. Conf. Trop. Fruit. Kuala Lampur, Malaysia. p. 317-320.

Campbell, C.W. 1985. Tropical fruit in Florida. HortScience 20:16.

Campbell, C.W., R.J. Knight, and R. Olszack. 1985. Carambola production in Florida. Proc. Fla. State Hort. Soc. 98:145-149.

Campbell, C.W. 1989. Carambola production in the United States. Proc. Interamer. Soc. Trop. Hort. 33:47-54.

Colburn, B. and S. Goldweber. 1961. Preparation of oolitic limestone soil for agricultural use. Proc. Fla. State Hort. Soc. 74:343-345.

Crane, J.H. 1994. The carambola (starfruit). Fact Sheet HS-12. Inst. Food Agr. Sci., Univ. of Florida, Gainesville.

Crane, J.H., L. Willis, S.P. Lara, and M. Ellenby. 1991. Short-term effects of manual topping of five-year-old 'Arkin' carambola trees. Proc. Fla. State Hort. Soc. 104:57-60.

Cull, B.W. 1986. A phenological cycling approach to tree crop productivity research. Acta Hort. 175:151-156.

Galán Saúco, V., U. Menini, and H. Tindall. 1993. Carambola Cultivation. Food and Agriculture Organization of the United Nations. Plant production and protection paper 108. Food and Agr. Org. of the United Nations, Rome.

George, H.L., J.H. Crane, B. Schaffer, Y. Li, and F.S. Davies. 2000. Effect of polyethylene and organic mulch on growth and yields of 'Arkin' carambola (Averrhoa carambola L.) in south Florida. Proc. Fla. State Hort. Soc. 113:5-11.

George, H.L., J.H. Crane, B. Schaffer, and Y. Li. 2001. Effect of polyethylene and organic mulch on flowering, pollen viability, percent fruit set, and fruit production of 'Arkin' carambola (Averrhoa carambola L.) in South Florida. Proc. Interamer. Soc. Trop. Hort. 44:72-77.

George, H.L., F.S. Davies, J.H. Crane, and B. Schaffer. 2002a. Root temperature effects on 'Arkin' carambola (Averrhoa carambola L.) trees. 1. Leaf gas exchange and 
water relations. Scientia Hort. 96:53-65.

George, H.L., F.S. Davies, J.H. Crane, and B. Schaffer. 2002b. Root temperature effects on 'Arkin' carambola (Averrhoa carambola L.) trees. II. Growth and mineral nutrition. Scientia Hort. 96:67-79.

Hsiao, T.C. and E. Acevedo. 1974. Plant responses to water deficits, water-use efficiency, and drought resistance. Agr. Meteorol. 14:59-84.

Ismail, M.R., S.W. Burrage, H. Tarmizi, and M.A. Aziz. 1994. Growth, plant water relations, photosynthesis rate, and accumulation of proline in young carambola plants in relation to water stress. Scientia Hort. 60:101-114.

Ismail, M.R. and K.M. Noor. 1996. Growth, water relations, and physiological processes of starfruit (Averrhoa carambola $\mathrm{L})$ plants under root growth restriction. Scientia Hort. 66:51-58.

Ismail, M.R., M.K. Yusaf, and A. Masturi. 1996. Growth and flowering of water stressed starfruit plants and response to ameliorated water stress. Proc. Intl. Conf. Trop. Fruit. Kuala Lampur, Malaysia. 2:97-106

Joyner, M.E. and B. Schaffer. 1989. Flooding tolerance of 'Golden Star' carambola trees. Proc. Fla. State Hort. Soc. 102:236-239.

Knight, Jr., R.J. 1982. Response of carambola seedling populations to Dade County's oolitic limestone soil. Proc. Fla. State Hort. Soc. 95:121-122.
Lakso, A.N. 1985. The effect of water stress on physiological processes in fruit crops. Acta Hort. 171:275-290.

Li, Y., J.Crane, B. Boman, and C. Balerdi. 2000. Irrigation management survey for tropical fruit crops in south Florida. Proc. Fla. State Hort. Soc. 113:40-42.

Miller, R.G. 1980. Simultaneous statistical inference. Springer-Verlag, New York.

Muñoz-Carpena, R., Y. Li, and T. Olczyk. 2002. Alternatives of low cost soil moisture monitoring devices for vegetable production in south Miami-Dade County. Univ. of Florida, IFAS, Coop. Ext. Serv. Publ. AVE 333.

Neter, J., W. Wasserman, and M.H. Kutner. 1990. Applied linear statistical models: Regression, analysis of variance, and experimental designs. Irwin, Boston.

Ngah, W., I. Ahmad, and A. Hassan. 1989. Carambola production, processing and marketing in Malaysia. Proc. Interamer. Soc. Trop. Hort. 33:30-43.

Noble, C.V., R.W. Drew, and V. Slabaugh. 1996. Soil survey of Dade County area, Florida. U.S. Dept. Agr., Natural Resources Conservation Serv., Washington, D.C

Núñez-Elisea, R.B. and J.H. Crane. 1998. Phenology, shoot development, and floral initiation of carambola (Averrhoa carambola L. cv. Arkin) in a subtropical environment. Proc. Fla. State Hort. Soc. 111:310-312.
Núñez-Elisea, R. and J.H. Crane. 2000. Selective pruning and crop removal increase early-season fruit production of carambola (Averrhoa carambola L.). Scientia Hort. 86:115-126.

Núñez-Elisea, R., B. Schaffer, M. Zekri, S.K. O'Hair, and J.H. Crane. 2001. In situ soil-water characteristic curves for tropical fruit orchards in trenched calcareous soil. HortTechnology 11:65-69.

Paltineanu, I.C. and J.L. Starr. 1997. Realtime soil water dynamics using multisensor capacitance probes: Laboratory calibration. Soil Sci. Soc. Amer. J. 61:1576-1585.

Reich, P.B. and R. Borchert. 1984. Water stress and tree phenology in a tropical dry forest in the lowlands of Costa Rica. J. Ecol. 72:61-74.

Salakpetch, S., D.W. Turner, and B. Dell. 1990. The flowering of carambola (Averrhoa carambola L.) is more strongly influenced by cultivar and water stress than by diurnal temperature variation and photoperiod. Scientia Hort. 43:83-94.

Tidbury, G.E. 1976. Averrhoaspp.,p. 291303. In: R.J. Garner and S.A. Chandhri (eds.). The propagation of tropical fruit trees. Cmwlth. Bur. Hort. Plantation Crops, East Malling, U.K.

Whiley, A., J. Saranah, B. Cull, and K. Pegg. 1988. Manage avocado tree growth cycles for productivity gains. Queensland Agr. J. 114:29-36. 